\title{
Evaluation of Red Pigment Extracted from Beetroot
}

\author{
Mohasen A. Farghaly, Ahmed H.S. Soliman and Abdelazim S. A. Abdellatif \\ Food Technology Research Institute, Agricultural Research Center, Giza, Egypt.
}

Received: 20 Oct. 2019 / Accepted 14 Dec. 2019 / Publication date: 30 Dec. 2019

\begin{abstract}
In the present study, the content of betalain, phenolic composition, and antioxidant activity of aqueous red beet extraction (Beta vulgaris L. subsp. vulgaris), In addition to the analysis of the influence of temperature, $\mathrm{pH}$, and time on the stability of the betalain extract content, as well as the consistency characteristics of French meringue applied as a coloring agent with lyophilized red beet extract were examined. Total phenolic and flavonoid contents were 220.57. $\mathrm{mg}$ GAE/g, $195.23 \mathrm{mg} \mathrm{QE} / \mathrm{g}$, respectively. Also, betaxanthin and betacyanin are equal to $30.86 \mathrm{mg}$ vulgaxanthin I equiv./g, and 20.19 $\mathrm{mg}$ betanin equiv./ g, respectively, in the lyophilized red beet extract. Betalains (vulgaxanthin I, Vulgaxanthain II, betanin, and isobetanin) and phenolics (Isovanillin, gallic acid, $P$-coumaric acid, chlorogenic acid, ferulic acid, kaempferol, quercetin, and myricetin) were identified. The percent of stability of total betalain of lyophilized red beet extract at $\mathrm{pH} 4$ and 5 after $120 \mathrm{~min}$ incubation at 50, 70 , and $90^{\circ} \mathrm{C}$ compare with zero time were (87.82 and $\left.82.33 \%\right),(61.35$ and $49.08 \%)$, and $(28.35$ and $16.46 \%$ ), respectively. DPPH radical scavenging activities (\%) and the ferric reducing power were risen with expanding concentration of tested lyophilized red beet extract from 0.1 to $1 \mathrm{mg} / 100 \mathrm{ml}$. With the addition of red beetroot extract, the lightness $\left(\mathrm{L}^{*}\right)$ of French meringue reduced considerably. Meanwhile, with the addition of beetroot extract, redness and yellowness improved significantly. The overall acceptability of meringue have been positively influenced using beetroot extract.
\end{abstract}

Keywords: red beet, temperature, $\mathrm{pH}$, time, stability, betalain, extract

\section{Introduction}

The red beet is a member of the family Chenopodiaceae (Angiosperm polygamy group: Amaranthaceae) (Beta vulgaris L. subsp. vulgaris). Due to the appearance of the swollen root resembling a Greek B, Beet is said to have got its name from the Greek letter beta, although it was the foliage beet variety, namely chard, which was domesticated in 2000 BC by the Greeks and Romans. With tuberous rootstocks, it is an erect annual herb. Concerning antioxidant properties, it ranks among the ten most potent vegetables. There are essentially four Beetroot varieties, known as Detroit dark red, Crimson Globe is widely grown in India, and Crosby Egyptian is another two. (Oyen, 2004; McGrath et al., 2007 and Chawla et al., 2016). Red beets are rich in phenolic acids also have a significant potential for antioxidants and can be used to make a natural dye (Antigo et al., 2018). Also, red beets are characterized to have medical effects as anti-inflammatory, antiallergenic, antiplatelet, antiatherogenic, cardioprotective, and vasodilatory (Balasundram et al., 2006). One of the important food quality parameters for attracting the consumers to edible products is color; it is called a consistency measure and is a necessary sensory trait for the approval of consumers. Many precautions of using synthetic dyes in manufacturing food products due to the health hazards, particularly in the initiation and development of chronic diseases as the transition in the histopathological function of the liver and kidney and an improvement in WBC, which means that it induces inflammation (Sahar and Manal, 2012). For this reason, many legal authorities commencd laws to prevent the use of synthetic dyes in food industries. So, food industries and food researchers are directed to the use of natural colorants. Carotenoids, chlorophylls, anthocyanins, and betalains are widely used in naturally derived food colorants (Stintzing and Carle, 2007).

Betalains are identified as aromatic indole molecules formed from tyrosine molecules composed of a molecule of chromophore and sugar; the betalains are composed of two main compounds, betacyanins, and betaxanthines, which look violet-red and yellow-orange, respectively to the human eye (Fig 1). Losses of violet pigments resulting in the heating phase of the betalain preparation solution improved along with increased $\mathrm{pH}$ levels. Changes in the content of violet pigments were observed to

Corresponding Author: Ahmed H. S. Soliman, Food Technology Research Institute, Agricultural Research Center, Giza, Egypt.E-mail: ah_salaam2003@yahoo.com 
correspond with a $\mathrm{pH}$ of 4.0-9.0.0. A rise in the content of yellow pigments was caused by the heating of the betalain preparation solution ('Mikołajczyk-Bator and Czapski, 2017).

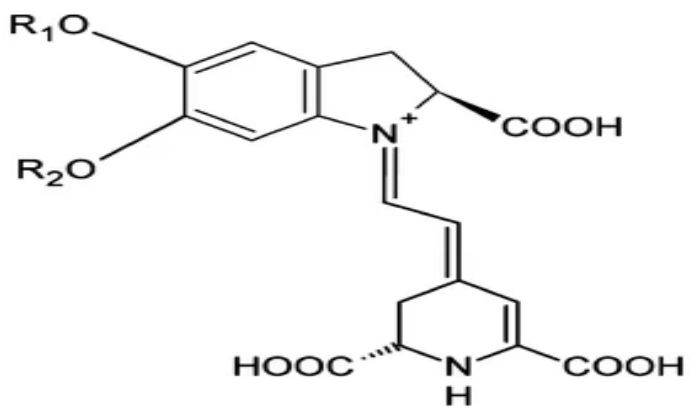

(I) Betacyanins

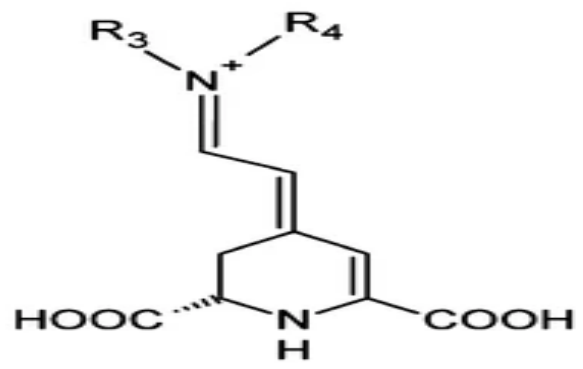

(II) Betaxanthins

Fig. 1: Betacyanine (I) and Betaxanthine (II) Structures. R1 and R2: moieties of hydrogen, acyl, or sugar; R3: a group of amine or amino acids; R4: normally hydrogen.

The stability of betalain is directly dependent on its $\mathrm{pH}$, which varies between 3 and 7 , with an optimal $\mathrm{pH}$ of between 4 and 5 . The scale of its spectrum is from pink to red. In the presence of light and oxygen, it is brittle and degraded when exposed to high temperatures (Antigo et al., 2018). Red beet extract could be a good natural colorant in food industries as candy products (jellies, ice sherbets, and gelatin/gellan based gummy candy), processed meat products (emulsified sausage), and bakery products (biscuits fortified with red beetroot powder) (Attia et al., 2013; Amnah, 2013; Jin et al., 2014). This experiment was intended to determine the chemical composition and to measure the antioxidant ability of the lyophilized red beet extract. A high-throughput chromatography-mass spectrometry process was used to perform the phenolic composition analysis. Besides, the color stability and sensory characteristics of the French meringue were examined.

\section{Materials and Methods}

\section{Materials}

The beetroot (Beta vulgaris L.), egg white, sugar powder, corn starch, vanilla powder, and Ponceau 4R colorant (E124) were obtained from a local market in Giza, Egypt. While, Folin Cioccalteu reagent, butylated hydroxyl toluin (BHT), Gallic acid, Sodium Carbonate, Potassium Ferricyanide, Ferric Chloride, Trichloroacetic acid, Ferric chloride, Amonium chloride, Quercetine, Sodium Hydroside, Ethanol and 2, 2-Diphenyl-1-Picryl-Hydrazyl (DPPH) all were obtained from sigma-Aldrich Chime, Steinheim, Germany.

\section{Methods}

\subsection{Extraction of crude pigment from red beetroot:}

The samples of beetroot were obtained from a local market in Giza, Egypt, cleaned and washed thoroughly under tap water and sliced then mashed into fine particles by an electric mixer (Barun, Combimax 700, Germany). An aqueous extraction was prepared from roots. Fifty grams of mashed red beetroots were homogenized with distilled water $(250 \mathrm{~mL})$ and macerated for $24 \mathrm{~h}$ at $5{ }^{\circ} \mathrm{C}$, the extract was filtered through cheese clothes. The insoluble portion was re-extracted twice for $24 \mathrm{~h}$ at $5{ }^{\circ} \mathrm{C}$ with $250 \mathrm{ml}$ of water. The obtained crude extracts were collected and centrifuged at $6000 \mathrm{rpm}$ for $30 \mathrm{~min}$ (Hermle Z206A, Germany), and evaporated at $40^{\circ} \mathrm{C}$ to a small volume (Rotary evaporator, Stuart, UK) and then the extract was freeze-dried (Snijders, Netherlands), at an absolute chamber pressure of 0.04 $\mathrm{Pa}$, freeze-drying began at $-40{ }^{\circ} \mathrm{C}$ (shelf temperature) and the process temperature at the end of the freeze-drying process reached room temperature within 48 hours. The collected powder was processed until it was examined in a hermetically sealed glass container. 


\subsection{Analysis of total phenolic compounds}

Total phenolic content was determined using the Folin-Ciocalteu process (Singleton and Rossi, 1965). The findings were expressed in $\mathrm{mg}$ of the equivalent of gallic acid (GAE)/g.

\subsection{Determination of total flavonoids}

Total flavonoids content was determined according to Ordonez et al. (2006) as follows: - In 0.5 $\mathrm{ml}$ of extraction solvent, an aliquot $(0.5 \mathrm{~mL})$ of $20 \mathrm{~g} \mathrm{l}^{-1} \mathrm{AlCl}_{3}$ was applied. The absorbance was estimated at $420 \mathrm{~nm}$ after $1 \mathrm{hr}$. The total flavonoids were expressed as equal to Quercetin (QE).

\subsection{Determination of betalain compounds with spectrophotometric analysis}

The content of betacyanins and betaxanthins in the lyophilized red beet extract was determined spectrophotometrically at $538 \mathrm{~nm}$ and $480 \mathrm{~nm}$ with a UV-Vis spectrometer, respectively according to the methods of Stintzing et al. (2003). The absorbance reading obtained was used to calculate the betalain concentration of the sample. The betalain content $(\mathrm{BC})$ was calculated as $\mathrm{BC}(\mathrm{mg} / \mathrm{g})=$ $[(\mathrm{A} \times \mathrm{DF} \times \mathrm{MW} \times 1000) /(\varepsilon \times \mathrm{L} * 1000)]$, where A: absorption, DF: dilution factor, and L: pathlength $(1 \mathrm{~cm})$ of the cuvette.

For quantification of betacyanins: the molecular weights (MW) equal $550 \mathrm{~g} / \mathrm{mol}$ and molar extinction coefficients $(\varepsilon)=60,000 \mathrm{~L} / \mathrm{mol} \mathrm{cm}$ in $\mathrm{H}_{2} \mathrm{O}$. While quantification of betaxanthins: molecular weights (MW) equal $308 \mathrm{~g} / \mathrm{mol}$ and molar extinction coefficients $(\varepsilon)$ equal 48,000 L/mol cm in $\mathrm{H}_{2} \mathrm{O}$.

\subsection{Identification and quantification of betalain and phenolic compounds with UPLC and LTQ- Orbitrap}

The identification of betalain and phenolic compounds were based on their molecular masses determined by Ultra-performance liquid chroma-tography heated electrospray ionization-mass spectrometry (UPLC-HESI-MS). The sample was analyzed using an Accela 600 UPLC system (Thermo Scientific, Germany) coupled to LTQ Orbitrap XL Hybrid FTMS operating in Heated Electrospray Ionization mode. Chromatographic separations of sample components were performed on Hypersil GOLD C18 column (Thermo Fisher Scientific, Germany, $50 \times 2.1 \mathrm{~mm}, 1.9 \mu \mathrm{m}$, particle size) at a flow rate of $0.40 \mathrm{~mL} \cdot \mathrm{min}^{-1}$. The column was eluted with $0.10 \%$ formic acid in water (A) and $0.10 \%$ formic acid in acetonitrile $98 \%$ (B). A stepwise gradient from 5 to $95 \%$ B was applied for 5 min, followed by 2 min isocratically at $95 \%$ B. according to Koubaier et al. (2013).

- Identification. The UPLC framework was coupled to an LTQ Orbitrap XL hybrid FTMS working in Heated Electrospray Ionization mode. The Mass Spectrometer was worked in negative mode with masses examined scan from 120-1000. MS settings were as per the following: capillary temperature $\left(270^{\circ} \mathrm{C}\right)$, sheath and helper gas pressures (35 and 10 subjective units), vaporizer temperature $\left(350^{\circ} \mathrm{C}\right)$. The particle source voltage was set to $-4.00 \mathrm{KV}$, the fine voltage to $-37.00 \mathrm{~V}$, and the cylinder focal point voltage to $-204.11 \mathrm{~V}$. Information acquisitions were done with Xcalibur QualBrowser programming.

- Quantification. Quantitative analyses were assessed with the external standard method. Standard calibration curves were established by plotting the height of peaks against seven different concentrations of polyphenolic compounds.

\subsection{DPPH Free Radical Scavenging Activity (RSA).}

In terms of hydrogen donation or radical scavenging potential, the antioxidant role of the lyophilized red beet extract has been calculated using the stable DPPH technique. At room temperature, the reaction mixture containing $1 \mathrm{ml}$ of lyophilized red beet extract and $1 \mathrm{ml}$ of DPPH $(0.2 \mathrm{~mm})$ at different concentrations $(0.1,0.3,0.5,0.7$, and $1 \mathrm{mg} / 100 \mathrm{ml})$ and $(100,200$, and $300 \mathrm{ppm})$ of butylated hydroxy toluene (BHT) was vigorously shaken and incubated in the dark. For reading the absorbance at $517 \mathrm{~nm}$, the UV-visible spectrophotometer was used. The radical scavenging activity was expressed as a percentage of inhibition and was calculated using the following formula:

$\% \mathrm{DPPH}=[$ Absorbance of Control - Absorbance of Sample / Absorbance of Control $] \mathrm{x} 100$.

From the graph plotted inhibition percentage against lyophilized red beet extract concentration, the concentration supplying 50 percent inhibition $\left(\mathrm{IC}_{50}\right)$ was determined. (Georgiev et al., 2010). 


\subsection{Ferric reducing antioxidant power (FRAP)}

Different amounts of the lyophilized red beet extract in methanol $(0.1,0.3,0.5,0.7$, and 1 $\mathrm{mg} / 100 \mathrm{ml}$ ) and $(100,200$, and $300 \mathrm{ppm})$ of butylated hydroxy toluene (BHT) were combined in separate tubes with $2.5 \mathrm{~mL}$ of phosphate buffer $(200 \mathrm{mM}, \mathrm{pH} 6.6)$, and $2.5 \mathrm{~mL}$ of $1 \%$ potassium ferricyanide. The antioxidant activity was measured by a ferric reduction assay. The tubes were put at $50{ }^{\circ} \mathrm{C}$ for 20 minutes in a boiling water bath, cooled quickly, and mixed with $2.5 \mathrm{~mL}$ of $10 \%$ trichloroacetic acid and $0.5 \mathrm{~mL}$ of $0.1 \%$ ferric chloride. The sum of iron (II)-ferricyanide complex formed was calculated by measuring at $700 \mathrm{~nm}$ after 10 minutes the formation of Perl's Prussian blue. Increased absorption of the reaction mixtures suggests increased power reduction (Rekha et al., 2012).

\subsection{Impacts of $\mathrm{pH}$, temperature, and time on the stability of lyophilized red beet extract.}

The stability of lyophilized red beet extract at high temperatures was tested in solutions, prepared at $\mathrm{pH} 3.0,4.0,5.0,6.0$, and 7.0 using $0.1 \mathrm{M}$ citrate-phosphate buffers and in water solution at $\mathrm{pH} 7.18$ then held in a thermostatically controlled water bath for 30,60, 90, and 120 minutes without light access. at 50,70 , and $90^{\circ} \mathrm{C}$, and cooled immediately in an ice bath. Total betalain was determined according to the methods of Stintzing et al. (2003).

\subsection{Application of the crude pigment to French meringue}

Following the Goldfarb (2016) technique, French meringue was developed with the following ingredients: $250 \mathrm{~g}$ egg white, $250 \mathrm{~g}$ regular and powdered sugar, $25 \mathrm{~g}$ corn starch, $5 \mathrm{~g}$ vanilla powder, and $0.1 \mathrm{ml}$ Ponceau 4R colorant (E124). In an electric mixer (Barun, Combimax 700, Germany), the egg whites were beaten to the point of snow, mixing the sugar slowly and continuing to beat for another 5 minutes, then adding corn starch and vanilla powder and eventually adding the synthetic color to the mold and baking for $75 \pm 5 \mathrm{~min}$ at a temperature of $85 \pm 5^{\circ} \mathrm{C}$ in an electric oven (Fisher Scientific, USA). Meringue color (Standard) was tested, and several percentages were tested to replace the synthetic colorant with the natural color (1, 1.5, 2, and $3 \mathrm{~g} / 100 \mathrm{~g}$ of fresh dough).

\subsection{Betalain extraction from French meringue}

Ten $\mathrm{ml}$ of 50 percent ethanol was combined with half a gram of the meringue sample, collected with ultrasound (Bandelin, Sonorex super, RK 51411, Germany) and the homogenate was centrifuged for $10 \mathrm{~min}$ at $6000 \mathrm{rpm}$. After centrifugation, the supernatant was collected as it is, and the extraction was repeated 2 more times to guarantee full betalain extraction. Furthermore, the supernatant collected was used for betalaine determination (Ravichandran et al., 2013).

\subsection{Color measurements}

The color was evaluated using a chromameter (Minolta CR 400, Minolta Camera, Co., Osaka, Japan) fitted with an $8 \mathrm{~mm}$ measuring head and a D65 illuminant at three separate sample points. The chromameter was calibrated using a standard white plate provided by the manufacturer. In the $\mathrm{L}^{*}, \mathrm{a}^{*}$, $b^{*}$ color space, color modifications were quantified. The hue angle $\left(h^{\circ}\right)$ when $a<0$ and $b>0$ was determined as $\mathrm{h}^{\circ}=\tan -1$ (b/a) (Parra-Campos and Ordóñez-Santos, 2019).

\subsection{The sensory evaluation of French meringue}

Sensory attributes (color, taste, odor, texture, and overall acceptability) of French meringue were evaluated directly after preparation by more than ten trained panelists in the Food Tech. Res. Inst. According to the method of (Chauhan and Sharma, 2003).

\subsection{Statistical analysis}

The results were analyzed statistically to establish mean values, standard deviation $( \pm \mathrm{SD})$. the data were statistically evaluated according to the 5 percent level of probability procedure by the least significant differences (L.S.D) (Snedecor and Cochran, 1980). 


\section{Results and Discussion}

\section{Yield and Chemical properties of lyophilized red beet extract}

The effective water extraction and the low-cost method were used to extract crude phenolic and betalain compounds. The chemical properties of lyophilized red beet extract were listed in Table (1).

Table 1: Total phenolic, flavonoids, and betalains of lyophilized red beet extract

\begin{tabular}{lc}
\hline Constituent & Value \\
\hline Total phenolic content (mg GAE/g of lyophilized extract) & $220.57 \pm 0.80$ \\
Total flavonoid content (mg Quercetin/g of lyophilized extract) & $195.23 \pm 0.70$ \\
\hline The betalain content (BC) & \\
Total betalains mg /g of lyophilized extract & $51.19 \pm 0.20$ \\
Total betaxanthin (mg vulgaxanthin I equiv. /g of lyophilized extract) & $30.86 \pm 0.20$ \\
Total betacyanin (mg betanin equiv. /g of lyophilized extract) & $20.19 \pm 0.18$ \\
Yields \% of extract ( $\mathrm{g} / 100 \mathrm{~g}$ plant) & $12.50 \pm 0.24$ \\
\hline
\end{tabular}

Values are mean \pm standard deviation of the means of triplicate determinations.

Data indicate that the total phenolic and flavonoid contents were $220.57 \pm 0.80 \mathrm{mg} \mathrm{GAE} / \mathrm{g}$ and $195.23 \pm 0.70 \mathrm{mg} \mathrm{QE} / \mathrm{g}$, respectively. Although betaxanthin and betacyanin were equal to $30.86 \pm 0.20$ mg vulgaxanthin I equiv./g, and $20.19 \pm 0.18 \mathrm{mg}$ betanin equiv./ g, respectively. Also, yield of water extraction of red beet root was $12.50 \pm 0.24 \mathrm{~g} / 100 \mathrm{~g}$ plant. Georgiev et al. (2010) showed that beetroot plant extracts contained $39.76 \pm 0.98 \mathrm{mg} / \mathrm{g}$ of betalains $(20.75 \pm 0.61 \mathrm{mg} / \mathrm{g}$ betacyanins and $19.01 \pm 0.39$ $\mathrm{mg} / \mathrm{g}$ betaxanthins). While Čanadanović-Brunet et al. (2011) reported that total contents of phenolics $(212.3 \pm 10 \mathrm{mg} / \mathrm{g}$ of dry extract), flavonoids $(200.50 \pm 10.00 \mathrm{mg} / \mathrm{g}$ of dry extract), total betaxanthins was $22.90 \pm 1.11 \mathrm{mg}$ vulgaxanthin-I equivalents per $\mathrm{g}$ of dry extract and total betacyanins were 18.78 $\pm 0.91 \mathrm{mg}$ betanin equivalents per $\mathrm{g}$ of dry extract in aqueous extraction of red beet. Also, Guldiken et al. (2016) mentioned that total phenolic and flavonoids in red beet were $255 \mathrm{mg} \mathrm{GAE} / \mathrm{g}$ and $260 \mathrm{mg} / \mathrm{g}$, respectively.

On the other hand, the obtained results by UPLC-HESI-MS analyses chromatogram (Fig 2) and Table (2) shows which depend on absorption spectrums, positive ion mass spectra $(\mathrm{m} / \mathrm{z})$, and retention time allowed the identification of 4 fractions with its molecular weights of lyophilized red beet extract. The spectrum was measured in the region between $100-1400 \mathrm{~nm}$ Within the individual fraction of violet pigments, the following were identified: The molecular ion in the positive ionization of betanin and isobetanin was $(\mathrm{m} / \mathrm{z}) 551$ in the visible region at $\lambda(538 \mathrm{~nm})$. While the molecular ion in the positive ionization of fraction of yellow pigments vulgaxanthin I and vulgaxanthin II in the visible region at $\lambda$ $(480 \mathrm{~nm})$ were 340 and 341, respectively. Kujala et al. (2001) and Kujala et al. (2002) mentioned that betanin and Isobetanin as betacyanins and a combination of vulgaxanthine I and II have been extracted from the water extracts. Betalains (vulgaxanthin I, betanin, and isobetanin) were analyzed using LCMS (Koubaier et al., 2014).

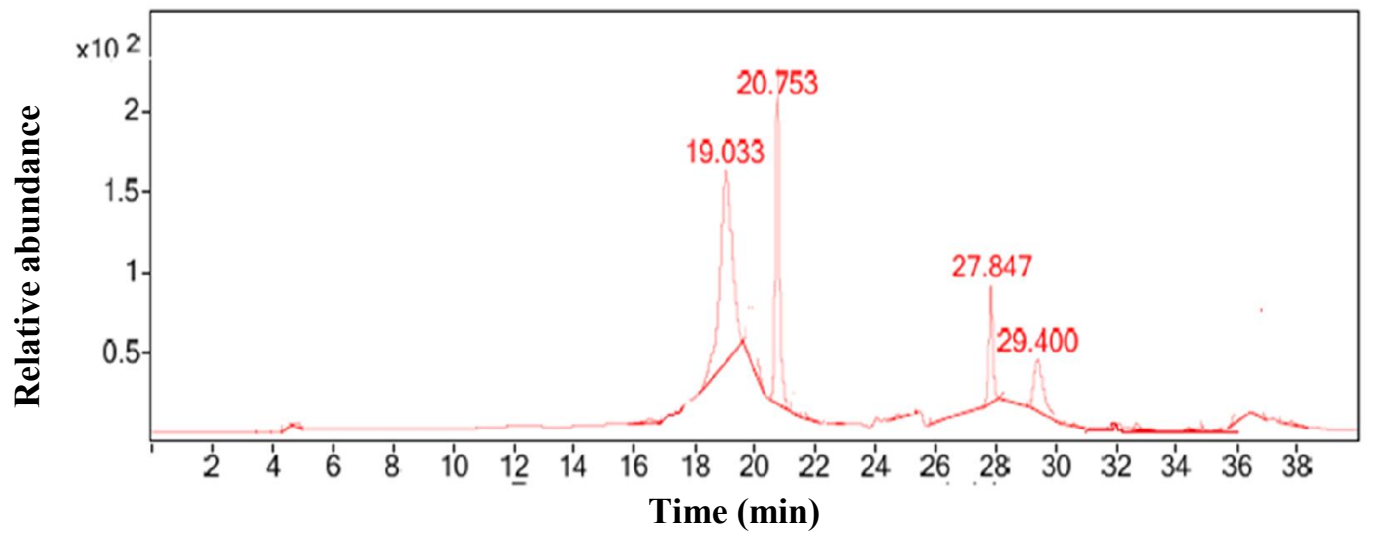

Fig. 2: Representative UPLC-HESI-MS analyses chromatogram of betalain component of lyophilized red beet extract 
Table 2: Mass spectral data (Retention time, mass spectrum on the positive ionization mode) of major compound detected of lyophilized red beet extract.

\begin{tabular}{ccccll}
\hline Peak & $\boldsymbol{\lambda}(\mathbf{n m})$ & $\mathbf{R t}(\mathbf{m i n})$ & $(\mathbf{M}+\mathbf{H})^{+}$-ion m/z & $\begin{array}{l}\text { Chemical } \\
\text { formula }\end{array}$ & Identification \\
\hline \multicolumn{5}{c}{ Betaxanthins } \\
1 & 480 & 19.033 & 340 & $\mathrm{C}_{14} \mathrm{H}_{17} \mathrm{~N}_{3} \mathrm{O}_{7}$ & Vulgazanthin I \\
2 & 480 & 20.753 & 341 & $\mathrm{C}_{14} \mathrm{H}_{17} \mathrm{~N}_{3} \mathrm{O}_{7}$ & Vulgaxanthain II \\
\hline \multicolumn{5}{c}{ Betacyanins } \\
4 & 538 & 27.847 & 551 & $\mathrm{C}_{24} \mathrm{H}_{27} \mathrm{~N}_{2} \mathrm{O}_{13}$ & Betanin \\
5 & 538 & 29.400 & 551 & $\mathrm{C}_{24} \mathrm{H}_{27} \mathrm{~N}_{2} \mathrm{O}_{13}$ & Isobetanin \\
\hline
\end{tabular}

Results in the table (3) The phenolic acids and flavonoids of lyophilized red beet extract were identified according to their retention times and spectral characteristics of their peaks against those of standards. for phenolic acids and flavonoids of lyophilized red beet extract from UPLC-MS analyses revealed the presence of five phenolic acids (Isovanillin, Gallic acid, $P$-coumaric acid, Chlorogenic acid, and Ferulic acid) was 20.53, 18.14, 13.64, 12.6, and $10.02 \mathrm{mg} / 100 \mathrm{~g}$, respectively. While the concertation of three flavonoids separation (Kaempferol, Quercetin, and Myricetin) were 2.91, 3.12, and $3.18 \mathrm{mg} / 100 \mathrm{~g}$ of lyophilized red beet extract, respectively. Koubaier $\boldsymbol{e t}$ al. (2014) mentioned that the phenolic composition extracts of roots and stems of red beet (gallic acid, ferulic acid, chlorogenic acid, caffeic acid, vanillic acid, syringic acid, ellagic acid, myricetin, quercetin, rutin, and kampferol) have been identified.

Table 3: Phenol composition (retention time, mass spectrum on the positive ionization mode) of major compound detected of lyophilized red beet extract.

\begin{tabular}{|c|c|c|c|c|}
\hline Rt (min) & $\begin{array}{c}(\mathbf{M}-\mathrm{H})^{- \text {ion }} \\
\mathrm{m} / \mathrm{z}\end{array}$ & $\begin{array}{l}\text { Chemical } \\
\text { formula }\end{array}$ & Identification & $\begin{array}{c}\text { Concentration } \\
\text { (mg/ 100g lyophilized red } \\
\text { beet extract) }\end{array}$ \\
\hline \multicolumn{5}{|c|}{ Phenolic acids } \\
\hline 12.72 & 197 & $\mathrm{C} 8 \mathrm{H} 8 \mathrm{O} 3$ & Isovanillin & 20.53 \\
\hline 13.53 & 203 & $\mathrm{C} 7 \mathrm{H} 6 \mathrm{O} 2$ & Gallic acid & 18.14 \\
\hline 13.72 & 310 & $\mathrm{C} 9 \mathrm{H} 8 \mathrm{O} 3$ & $P$-coumaric acid & 13.64 \\
\hline 17.04 & 355 & C16H18O9 & Chlorogenic acid & 12.60 \\
\hline 20.04 & 193 & $\mathrm{C} 10 \mathrm{H} 10 \mathrm{O} 4$ & Ferulic acid & 10.02 \\
\hline \multicolumn{5}{|c|}{$\begin{array}{l}\text { Flavonoids } \\
\end{array}$} \\
\hline 22.99 & 286 & $\mathrm{C} 15 \mathrm{H} 10 \mathrm{O} 6$ & Kaempferol & 2.91 \\
\hline 25.12 & 301 & $\mathrm{C} 15 \mathrm{H} 10 \mathrm{O} 7$ & Quercetin & 3.12 \\
\hline 28.09 & 317 & $\mathrm{C} 15 \mathrm{H} 10 \mathrm{O} 8$ & Myricetin & 3.18 \\
\hline
\end{tabular}

2. Effect of temperature, time, and pH level on stability of total betalin

The stability of total betalain of lyophilized red beet extract was evaluated in buffer solution at various $\mathrm{pH}$ values of buffer ranging from 3 to 7.0 as well as water at $\mathrm{pH} 7.18$. The results in Table (4) presented that, there is no significant difference $(\mathrm{p}<0.05)$ in total betalain at $\mathrm{pH} 5,50^{\circ} \mathrm{C}$ and incubation period 0 and $30 \mathrm{~min}$. Meanwhile, the total betalain was more stable at $\mathrm{pH} 4$ and 5, which were 46.37 and $46.77 \mathrm{mg} / 100 \mathrm{ml}$, respectively. Though, by expanding the $\mathrm{pH}$ over 5 or diminishing the $\mathrm{pH}$ underneath 4, the total betalain content was significantly decreased to 37.69 and $39.45 \mathrm{mg} / 100 \mathrm{ml}$, respectively.

The statistical analysis showed a significant difference $(p<0.05)$ in total betalain content by the raising of temperature from 50 to $90^{\circ} \mathrm{C}$ was 55.92 to $23.30 \mathrm{mg} / 100 \mathrm{ml}$, respectively. From the same Table, it could be noticed that the increase of incubation period of total betalain from 0: $120 \mathrm{~min}$ on buffer solutions of red pigment at different $\mathrm{pH}$ and temperatures resulted led to significantly decreased from 61.53: $29.46 \mathrm{mg} / 100 \mathrm{ml}$, respectively. 
Table 4: Effect of temperature, time, and $\mathrm{pH}$ level on stability of total betalains ( $\mathrm{mg} / 100 \mathrm{ml})$

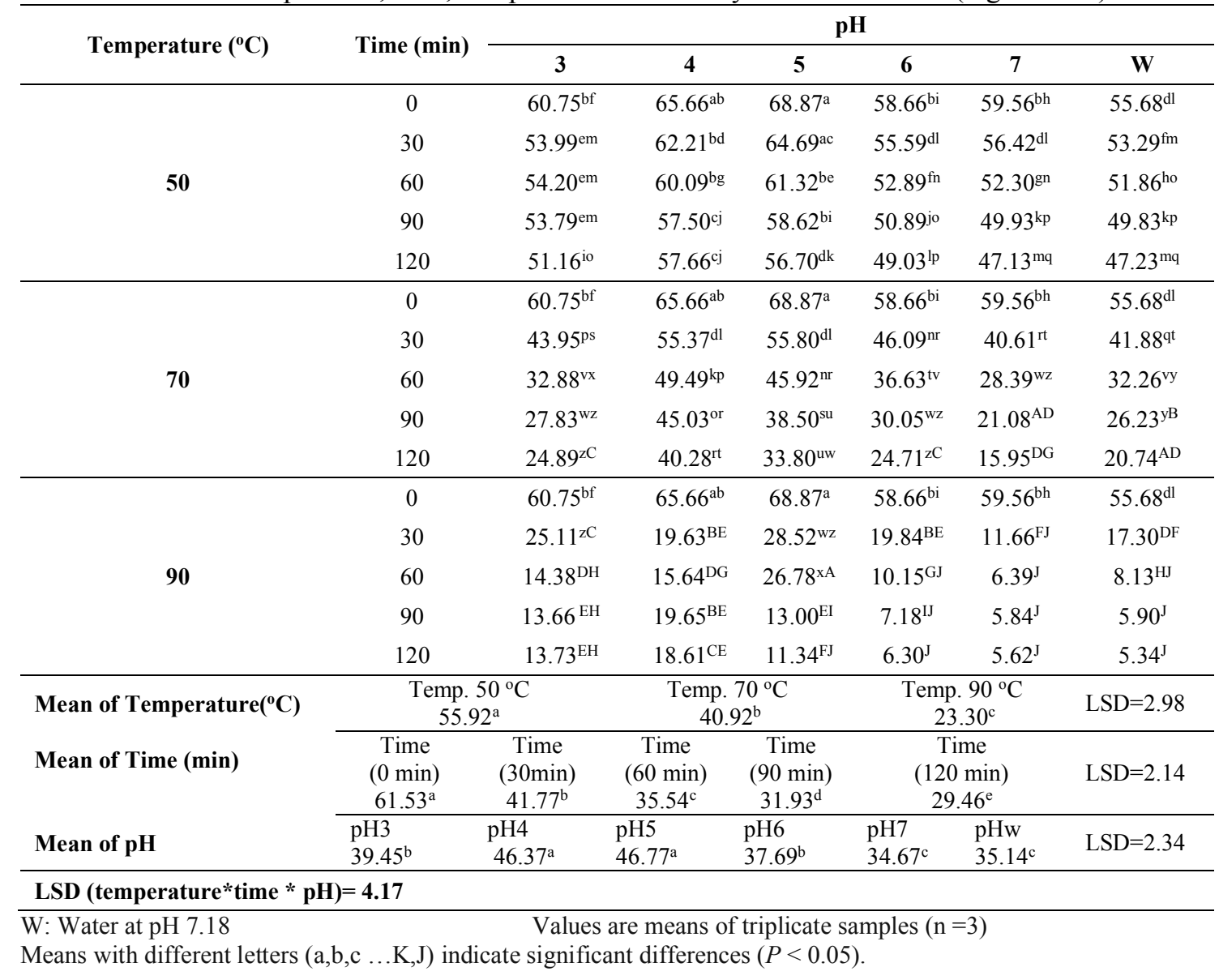

The percent of stability of total betalain of lyophilized red beet extract at $\mathrm{pH} 4$ and 5 after 120 min incubation at 50,70 , and $90^{\circ} \mathrm{C}$ compare with zero time were (87.82 and $\left.82.33 \%\right),(61.35$ and 49.08 $\%)$ and (28.35 and $16.46 \%)$, respectively. While the percent of stability of total betalain of lyophilized red beet extract in water $\mathrm{pH} 7.18$ after 120 min incubation at 50,70 , and $90^{\circ} \mathrm{C}$ compare with zero time were $84.82,37.25$, and $9.59 \%$, respectively. This finding agrees with many earlier studies JaniszewskaTurak et al. (2016) mentioned that betalains are oil-insoluble however water-dissolvable. Contingent on the $\mathrm{pH}$ of the environment, they take the brownish $(\mathrm{pH}>8.5)$, blue-violet $(6.5-8.0)$, red purple (3.0$6.5)$, or red-violet shading $(\mathrm{pH}<3.0)$, yet their most noteworthy dependability is seen at the $\mathrm{pH} 4-5$ territory. Betalains are feebly impervious to light and temperature above $70{ }^{\circ} \mathrm{C}$. The shading may then change from red to yellow. Mikołajczyk-Bator and Czapski (2017) showed that the violet pigments (betanin) of red beet were decreased at the thermal process of the betalain preparation solution expanded alongside rising $\mathrm{pH}$ levels. Changes in violet color content were seen as connected with a $\mathrm{pH}$ of 4.0 9.0. The thermal process at $90^{\circ} \mathrm{C} / 30 \mathrm{~min}$ for the betalain solution led to an increase in the level of yellow pigment (vulgaxanthins). The increase of temperature and $\mathrm{pH}$ value of preparation of betalain was connected with expanded damages of betanin (violet pigment). Hussain et al. (2018) stated that the thermal process, betanin can be corrupted by isomerization and evacuation of the carboxyl group which gradually blurs the red shading followed by pale earthy colored shading, at some point or another. Moreover, Betanin is consistently going from 5.5 to $5.8 \mathrm{pH}$ inside seeing oxygen. Vulgaxanthin is significantly consistent in the extent of $\mathrm{pH} 5.0-6.0$. 
3. Evaluation of antioxidant activity procedures of lyophilized beetroot extract compared with synthetic antioxidant (BHT).

\subsection{DPPH Free Radical Scavenging Activity (RSA).}

The free radical-scavenging capacity of lyophilized red beet extract at different concentrations was measured by DPPH assay and ferric reducing antioxidant power (FRAP) is given in Table (5). DPPH radical scavenging activities (\%) were risen with expanding concentration of tested lyophilized red beet extract from 0.1 to $1 \mathrm{mg} / 100 \mathrm{ml}$. At $1 \mathrm{mg} / 100 \mathrm{ml}$ of lyophilized red beet extract, a $10.84 \%$ DPPH was scavenging, while it was $85.60 \%$ in the presence of $1 \mathrm{mg} / 100 \mathrm{ml}$. however, it was $62.06 \%$ in the presence of $200 \mathrm{ppm} \mathrm{BHT,} \mathrm{Generally,} \mathrm{the} \mathrm{lyophilized} \mathrm{red} \mathrm{beet} \mathrm{extract} \mathrm{at} 0.7$ and $1 \mathrm{mg} / 100 \mathrm{ml}$ was found to exhibit a higher significant DPPH radical scavenging activity $(\mathrm{P} \leq 0.05)$ than that of BHT at concentration $200 \mathrm{ppm}$. The concentration of lyophilized red beet extract providing 50\% inhibition of $\mathrm{DPPH}\left(\mathrm{IC}_{50}\right)$ was used in evaluating the efficiency of the extract. The $\mathrm{IC}_{50}$ value of the extract studied was found to be $0.484 \mathrm{mg} / 100 \mathrm{ml}$ and was equivalent to the synthesis antioxidant $\mathrm{BHT}\left(\mathrm{IC}_{50}=149.5\right.$ ppm).

Table 5: Antioxidant activity of lyophilized red beet extract compared with BHT:

\begin{tabular}{|c|c|c|}
\hline \multirow[b]{2}{*}{ Concentrations } & \multicolumn{2}{|c|}{ Antioxidant activity (\%) } \\
\hline & $\begin{array}{c}\text { DPPH radical scavenging activity } \\
(\%)\end{array}$ & $\begin{array}{c}\text { The absorbance of ferric reducing } \\
\text { power }\end{array}$ \\
\hline $0.1 \mathrm{mg} / 100 \mathrm{ml}$ & $10.84 \pm 0.84$ & $0.174 \pm 0.013$ \\
\hline $0.3 \mathrm{mg} / 100 \mathrm{ml}$ & $39.98 \pm 0.62$ & $0.378 \pm 0.011$ \\
\hline $0.5 \mathrm{mg} / 100 \mathrm{ml}$ & $59.03 \pm 0.45$ & $0.680 \pm 0.017$ \\
\hline $0.7 \mathrm{mg} / 100 \mathrm{ml}$ & $68.73 \pm 0.67$ & $0.808 \pm 0.009$ \\
\hline $1 \mathrm{mg} / 100 \mathrm{ml}$ & $85.60 \pm 1.20$ & $1.079 \pm 0.069$ \\
\hline $\mathrm{IC}_{50}(\mathrm{mg} / 100 \mathrm{ml})$ & 0.484 & -- \\
\hline BHT (100ppm) & $38.39 \pm 1.72$ & $0.315 \pm 0.009$ \\
\hline BHT (200ppm) & $62.06 \pm 1.34$ & $0.798 \pm 0.014$ \\
\hline BHT (300ppm) & $84.36 \pm 0.08$ & $0.998 \pm 0.011$ \\
\hline $\mathrm{IC}_{50}(\mathrm{ppm})$ & 149.50 & -- \\
\hline
\end{tabular}

Values are mean \pm standard deviation of the means of triplicate determinations.

\subsection{Ferric reducing antioxidant power (FRAP)}

In ferric reducing antioxidant power (FRAP), the yellow shade of the test arrangement changes to green or blue shading relying upon the reducing power of antioxidant samples. A higher absorbance indicates a greater reducing power of the ferric. An increase in the ferric reducing power (FRAP) was observed in the lyophilized red beet extract with increasing concentration. However, the results revealed that the ferric reducing power value at $1 \mathrm{mg} / 100 \mathrm{ml}(1.079)$ was the highest one compared to BHT (0.998) at a concentration of $300 \mathrm{ppm}$. Koubaier et al. (2014) showed that the distinction in the antioxidant activity of the diverse red beet extracts was ascribed to the distinction in betalains and total phenol content. Saani and Lawrence (2016) stated that the beetroot is a promising wellspring of natural antioxidant and antibacterial agent and definitely provides and certainly gives an option towards synthetic antioxidant because due to its valuable properties. Nahla et al. (2018) mentioned that ethanolic extracts of beetroot are wealthy in all-out phenols and flavonoids. Phenolic mixes have strong cell reinforcement exercises as they can adequately search free radicals and chelate change metals among different properties.

The results in a table (6) show the impact of thermal treatment of French baked meringues at $75 \pm 5 \mathrm{~min}$ at a temperature of $85 \pm 5^{\circ} \mathrm{C}$ on total betaxanthin (mg vulgaxanthin I equiv. $/ 100 \mathrm{~g}$ meringues) and total betacyanin ( $\mathrm{mg}$ betanin equiv. $/ 100 \mathrm{~g}$ meringues). The level of betaxanthin and betacyanin stability was improved by increasing the percentage of lyophilized red beet extract added. The content of betaxanthin and betacyanin were $39.64 \pm 1.51$, and $35.91 \pm 1.36$ percent, respectively, at $1 \%$ of the lyophilized red beet extract in French meringues. Even though the content of betaxanthin and betacyanin in French meringues was $64.00 \pm 0.79,62.21 \pm 1.01 \%$, at $3 \%$ of the lyophilized red beet extract. 
Table 6: Betalain content stability at different levels of lyophilized red beet extract formulation in French meringues

\begin{tabular}{|c|c|c|c|c|c|c|}
\hline \multirow{2}{*}{$\begin{array}{l}\text { Concentration } \\
\text { Extract } \\
(\mathrm{g} / \mathbf{1 0 0 g})\end{array}$} & \multicolumn{2}{|c|}{$\begin{array}{l}\text { Total betaxanthin } \\
\text { mg/100g meringues }\end{array}$} & \multirow{2}{*}{$\begin{array}{c}* \text { Stability } \\
(\%)\end{array}$} & \multicolumn{2}{|c|}{$\begin{array}{c}\text { Total betacyanin mg/100g } \\
\text { meringues }\end{array}$} & \multirow{2}{*}{$\begin{array}{c}* \text { Stability } \\
(\%)\end{array}$} \\
\hline & $\begin{array}{l}\text { Before } \\
\text { baking }\end{array}$ & $\begin{array}{c}\text { After } \\
\text { baking }\end{array}$ & & $\begin{array}{c}\text { Before } \\
\text { baking }\end{array}$ & $\begin{array}{c}\text { After } \\
\text { baking }\end{array}$ & \\
\hline 1 & $30.86^{\mathrm{d}} \pm 0.65$ & $12.24^{\mathrm{d}} \pm 0.68$ & $39.64^{\mathrm{d}} \pm 1.51$ & $20.19^{d} \pm 0.08$ & $7.25^{\mathrm{d}} \pm 0.30$ & $35.91^{\mathrm{d}} \pm 1.36$ \\
\hline 1.5 & $46.29^{c} \pm 0.98$ & $21.59^{\mathrm{c}} \pm 0.92$ & $46.63^{\mathrm{c}} \pm 0.99$ & $37.03^{\mathrm{c}} \pm 1.89$ & $15.62^{\mathrm{c}} \pm 2.40$ & $42.23^{\mathrm{c}} \pm 0.88$ \\
\hline 2 & $61.71^{\mathrm{b}} \pm 1.31$ & $34.13^{b} \pm 0.71$ & $55.30^{\mathrm{b}} \pm 0.52$ & $40.39^{\mathrm{b}} \pm 0.15$ & $21.23^{\mathrm{b}} \pm 0.15$ & $52.56^{\mathrm{b}} \pm 0.69$ \\
\hline 3 & $92.57^{\mathrm{a}} \pm 1.96$ & $59.24^{\mathrm{a}} \pm 1.59$ & $64.00^{\mathrm{a}} \pm 0.79$ & $60.58^{\mathrm{a}} \pm 0.26$ & $37.69^{\mathrm{a}} \pm 0.63$ & $62.21^{\mathrm{a}} \pm 1.01$ \\
\hline LSD 0.05 & 2.48 & 1.96 & 1.85 & 2.55 & 2.36 & 1.91 \\
\hline
\end{tabular}

Stability $=($ After baking/Before baking)*100

Values are mean \pm standard deviation of the means of triplicate determinations.

Means with different letters $(a, b, c \ldots)$ indicate significant differences $(P<0.05)$.

The findings were expressed as tri-stimulus values of French meringues $(\mathrm{L}=$ lightness $(0=$ black, $100=$ white $), \mathrm{a}(-\mathrm{a}=$ greenness, $+\mathrm{a}=$ redness $)$ and $\mathrm{b}(-\mathrm{b}=$ blueness, $+\mathrm{b}=$ yellowness $))$ were substantially influenced by the colorant source $(\mathrm{p}<0.01)$ (Table 7$)$. By maximizing the amount $(1,1.5$, 2 , and 3 percent) of lyophilized red beet extract, the higher colour $L^{*}$ of French meringues with lyophilized red beet extract was increased by $81.23 \pm 0.07,63.77 \pm 0.32,58.90 \pm 0.06$, and $49.44 \pm 0.18$, respectively. By comparison, the colour values a* (representing the redness), b* (representing the yellowness), ( $\left.\mathrm{c}^{*}\right)$, and $\left(\mathrm{h}^{*}\right)$ are diminished by increasing the quantity of lyophilized red beet extract from $1 \%$ to $3 \%$. The colour values $\left(\mathrm{a}^{*}\right),\left(\mathrm{b}^{*}\right),\left(\mathrm{c}^{*}\right)$ and $\left(\mathrm{h}^{*}\right)$ were $6.21 \mathrm{~d} \pm 0.03,19.45 \pm 0.13,13.92 \pm 0.08$, and $62.42 \pm 0.09$ respectively at 1 percent of the lyophilized red beet extract in French meringues, while $9.55 \pm 0.33,33.91 \pm 0.08,25.77 \pm 0.15$, and $69.54 \mathrm{a} \pm 0.30$ respectively were used at 3 percent of the lyophilized red beet extract in French meringues. The colour of French meringues is largely influenced by sugars under certain conditions. Maillard reactions, which are non-enzymatic browning due to reducing sugars, and caramelization reactions due to heat unstable sugars, are greatly affected. It is known that the reaction is caused by high temperature, which affects the chromaticity of cookies (Lee et al., 2007). Therefore, the colour change of the meringues in this study is also due to the combination of heat-induced changes in betalain content of red beetroot and browning reactions by sugars and amino acids in meringues ingredients. It is believed that it has influenced the colour change of French meringues.

Table 7: Color analysis of French meringues with different concentration of lyophilized red beet extract

\begin{tabular}{|c|c|c|c|c|c|}
\hline Concentration Extract (g/100g) & $\mathbf{L}^{*}$ & $\mathbf{a}^{*}$ & $\mathbf{b}^{*}$ & $\mathrm{c}^{*}$ & $\mathbf{h}^{*}$ \\
\hline $\mathbf{0}^{*}$ & $80.63^{\mathrm{a}} \pm 0.04$ & $7.91^{\mathrm{c}} \pm 0.05$ & $15.66^{\mathrm{e}} \pm 0.33$ & $17.30^{\mathrm{d}} \pm 0.06$ & $62.53^{\mathrm{d}} \pm 0.13$ \\
\hline 1 & $81.23^{\mathrm{a}} \pm 0.07$ & $6.21^{\mathrm{d}} \pm 0.03$ & $19.45^{\mathrm{d}} \pm 0.13$ & $13.92^{\mathrm{e}} \pm 0.08$ & $62.42^{\mathrm{d}} \pm 0.09$ \\
\hline 1.5 & $63.77^{\mathrm{b}} \pm 0.32$ & $8.09^{\mathrm{c}} \pm 0.05$ & $21.62^{\mathrm{c}} \pm 0.08$ & $19.54^{\mathrm{c}} \pm 0.15$ & $64.97^{c} \pm 0.03$ \\
\hline 2 & $58.90^{\mathrm{c}} \pm 0.06$ & $8.80^{\mathrm{b}} \pm 0.16$ & $27.84^{\mathrm{b}} \pm 0.07$ & $23.67^{b} \pm 0.28$ & $66.73^{\mathrm{b}} \pm 0.20$ \\
\hline 3 & $49.44^{\mathrm{d}} \pm 0.18$ & $9.55^{\mathrm{a}} \pm 0.33$ & $33.91^{\mathrm{a}} \pm 0.08$ & $25.77^{\mathrm{a}} \pm 0.15$ & $69.54^{\mathrm{a}} \pm 0.30$ \\
\hline LSD 0.05 & 0.64 & 0.42 & 0.44 & 0.42 & 0.46 \\
\hline
\end{tabular}

$0 *$ synthetic color (control sample) Values are mean \pm standard deviation of the means of triplicate determinations. Means with different letters $(\mathrm{a}, \mathrm{b}, \mathrm{c} \ldots)$ indicate significant differences $(P<0.05)$.

No significant differences in flavor preference were found between the control sample and the French meringue with 1,2, and 3\% of the lyophilized red beet extract. However, with 1.5 percent, there were significant variations in flavor between the control sample and French meringue. There were no significant differences in odor preference between the control sample and French meringue with 1, 1.5, and $3 \%$ of the lyophilized red beet extract. However, there were significant differences in taste between the control sample and French meringue with $2 \%$. The addition of vanilla to the meringue has a positive influence on the consistency of the flavor since it can hide any unusual taste arising from the addition of lyophilized red beet extract to the meringue. No significant differences in texture preference were found between the control sample and the French meringue with $1 \%$ of the lyophilized red beet extract. 
And although increasing the proportion of lyophilized red beet extract to meringue more than $1 \%$, had a significant effect on the texture quality of meringue. The preference for Overall acceptability was the highest in the control group at 8.78 followed by meringue with 2 to $3 \%$ were 8.46 , and 8.51 , the lowest scores of overall acceptability was in French meringue with 1 to $1.5 \%$. Since the characteristic color of the meringue was more yellow at 1 , and $1.5 \%$ of the lyophilized red beet extract because of an increase in the concentration of betaxanthin due to the effect of heat treatment, and by increasing the concentration of the added extract from 2 to $3 \%$ of the lyophilized red beet extract, the resulting meringue color was redness due to Increased residual betacyanin concentration after heat treatment. The food processing steps can have a detrimental influence on pigment stability, while the food matrix and other food ingredients may have positive effects (Manchali et al., 2013). Red beet extract could be a good natural colorant in emulsified pork sausage, Jellies, and ice sherbets, gelatin/gellan based gummy candy (Attia et al., 2013; Jin et al., 2014). Also, Amnah (2013) stated that the biscuits fortified with red beetroot powder were almost identical to the control biscuits, either powder or extract of appropriate quality.

Table 8: Sensory evaluation score of French meringues containing various levels of lyophilized red beet extract.

\begin{tabular}{|c|c|c|c|c|c|}
\hline Concentration Extract (\%) & Color & Taste & Odor & Texture & $\begin{array}{c}\text { Overall } \\
\text { acceptability }\end{array}$ \\
\hline 0* & $8.70^{\mathrm{a}}$ & $8.75^{\mathrm{a}}$ & $8.70^{\mathrm{a}}$ & $8.95^{\mathrm{a}}$ & $8.99^{\mathrm{a}}$ \\
\hline 1 & $6.55^{\mathrm{c}}$ & $8.55^{\mathrm{ab}}$ & $8.65^{\mathrm{a}}$ & $8.80^{\mathrm{ab}}$ & $7.14^{\mathrm{b}}$ \\
\hline 1.5 & $7.55^{\mathrm{b}}$ & $8.40^{\mathrm{b}}$ & $8.50^{\mathrm{ab}}$ & $8.45^{\mathrm{b}}$ & $8.01^{\mathrm{b}}$ \\
\hline 2 & $8.55^{\mathrm{a}}$ & $8.55^{\mathrm{ab}}$ & $8.25^{\mathrm{b}}$ & $8.55^{\mathrm{b}}$ & $8.66^{\mathrm{a}}$ \\
\hline 3 & $8.75^{\mathrm{a}}$ & $8.45^{\mathrm{ab}}$ & $8.40^{\mathrm{ab}}$ & $8.45^{\mathrm{b}}$ & $8.61^{\mathrm{a}}$ \\
\hline LSD 0.05 & 0.389 & 0.328 & 0.371 & 0.367 & 0.414 \\
\hline
\end{tabular}

0 * synthetic color (control sample)

Means with different letters $(\mathrm{a}, \mathrm{b}, \mathrm{c} \ldots)$ indicate significant differences $(P<0.05)$.

\section{Conclusion}

Due to its higher phenol and flavonoid contents, the lyophilized beetroot extract has high antioxidant properties. It had characteristic stability of $\mathrm{pH} 4$ and 5 and was more stable at $50{ }^{\circ} \mathrm{C}$. It was also observed the stability of betaxanthin and betacyanin was higher than $60 \%$ of initial added betaxanthin and betacyanin in French meringue. The preference for overall acceptability was the highest in the control group at 8.78 followed by meringue with 2 to $3 \%$ were 8.46 and 8.51 , respectively. The lowest scores of overall acceptability were in French meringue with 1 to $1.5 \%$ of the lyophilized beetroot extract.

\section{Acknowledgment}

The authors are grateful to Prof. Dr. Gaspar Ros-Berruezo, Food Science and Human Nutrition Dept., Faculty of Veterinary Sciences, Murcia University, Spain and Dr. Esmat Aly, Researcher at Food Technology Research Institute, Giza, Egypt, for the assistance in carrying out the analyses of root red beet extract betalain and polyphenols using UPLC-HESI-MS analyses at the University of Murcia, Spain.

\section{References}

Amnah, M.A., 2013. Nutritional, sensory and biological study of biscuits fortified with red beet roots. Life Science Journal, 10(3): 1579-1584.

Antigo, J.L.D., R.D.C. Bergamasco, and G.S. Madrona, 2018. Effect of $\mathrm{pH}$ on the stability of red beet extract (Beta vulgaris L.) microcapsules produced by spray drying or freeze-drying. Food Science and Technology, 38(1): 72-77.

Attia, Gamila Y., Moussa, M. E. M. and E.R. Sheashea, 2013. Characterization of red pigments extracted from red beet (Beta vulgaris L.) and its potential uses as antioxidant and natural food colorants. Egyptian Journal of Agricultural Research, 91.3: 1095-1110. 
Balasundram, N., K. Sundram and S. Samman, 2006. Phenolic compounds in plants and agri-industrial by-products: Antioxidant activity, occurrence, and potential uses. Food chemistry, 99(1): 191203.

Čanadanović-Brunet, J.M., S. S. Savatović, G.S. Ćetković, J.J. Vulić, S.M. Djilas, S.L. Markov, and D.D. Cvetković, 2011. Antioxidant and antimicrobial activities of beet root pomace extracts. Czech Journal of Food Sciences, 29(6): 575-585.

Chauhan, V.S. and A. Sharma, 2003. Studies on organoleptic properties of food products from fresh egg and egg powder through principal component analysis. Food/Nahrung, 47(2): 102-105.

Chawla, H., M. Parle, K. Sharma and M. Yadav, 2016. Beetroot: A health promoting functional food. Inventi Rapid: Nutraceuticals, 1(1): 0976-3872.

Georgiev, V.G., J. Weber, E.M. Kneschke, P.N. Denev, T. Bley and A.I. Pavlov, 2010. Antioxidant activity and phenolic content of betalain extracts from intact plants and hairy root cultures of the red beetroot Beta vulgaris cv. Detroit dark red. Plant foods for human nutrition, 65(2): 105-111.

Goldfarb, W., 2016. Making a Balinese Meringue. International Journal of Gastronomy and Food Science, 4: 12-18.

Guldiken, B., G. Toydemir, K. Nur Memis, S. Okur, D. Boyacioglu and E. Capanoglu, 2016. HomeProcessed Red Beetroot (Beta vulgaris L.) Products: Changes in Antioxidant Properties and Bioaccessibility. Int. J. Mol. Sci., 17: 858.

Hussain, E.A., Z. Sadiq, and M. Zia-Ul-Haq, 2018. Betalains as Colorants and Pigments. In Betalains: Biomolecular Aspects (125-137). Springer, Cham.

Janiszewska-Turak, E., A. Pisarska, and J.B. Królczyk, 2016. Natural food pigments application in food products. Nauka Przyroda Technologie, 10(4): 51.

Jin, S.K., Choi, J.S., S.S. Moon, J.Y. Jeong, and G.D. Kim, 2014. The assessment of red beet as a natural colorant, and evaluation of quality properties of emulsified pork sausage containing red beet powder during cold storage. Korean journal for food science of animal resources, 34(4): 472.

Koubaier, H.B.H., I. Essaidi, A. Snoussi, S. Zgoulli, M.M. Chaabouni, P. Thonart, and N. Bouzouita, 2013. Effect of Saccharomyces cerevisiae fermentation on the colorants of heated red beetroot extracts. African Journal of Biotechnology, 12(7): 728:734.

Koubaier, H.B.H., A. Snoussi, I. Essaidi, M.M. Chaabouni, P. Thonart, and N. Bouzouita, 2014. Betalain and phenolic compositions, antioxidant activity of Tunisian red beet (Beta vulgaris L. conditiva) roots and stems extracts. International journal of food properties, 17(9): 1934-1945.

Kujala, T.S., M.S. Vienola, K.D. Klika, J.M. Loponen, and K. Pihlaja, 2002. Betalain and phenolic compositions of four beetroot (Beta vulgaris) cultivars. European Food Research and Technology, 214(6): 505-510.

Kujala, T., J. Loponen, and K. Pihlaja, 2001. Betalains and phenolics in red beetroot (Beta vulgaris) peel extracts: extraction and characterisation. Zeitschrift für Naturforschung C, 56(5-6): 343-348.

Lee, S.J., J.H. Shin, D.J. Choi, and O. Kwen, 2007. Quality characteristics of cookies prepared with fresh and steamed garlic powders. Journal of the Korean Society of Food Science and Nutrition, 36(8): 1048-1054.

Manchali, S., K.N.C. Murthy, S. Nagaraju, and B. Neelwarne, 2013. Stability of betalain pigments of red beet. In Red beet biotechnology (55-74). Springer, Boston, MA.

Mikołajczyk-Bator, K. and J. Czapski, 2017. Effect of pH changes on antioxidant capacity and the content of betalain pigments during the heating of a solution of red beet betalains. Polish Journal of Food and Nutrition Sciences, 67(2): 123-128.

McGrath, J.M., M. Saccomani, P. Stevanato, and E. Biancardi, 2007. Beet. In Genome mapping and molecular breeding in plants, Vegetables, vol. 5, ed. C. Kole, 191-207. Berlin: Springer.

Nahla, T.K., S.U. Wisam, and N.M. Tariq, 2018. Antioxidant activities of beetroot (Beta vulgaris L.) extracts. Pak. J. Nutr, 17, 500-505.

Ordonez, A.A.L., J.D. Gomez, and M.A. Vattuone, 2006. Antioxidant activities of Sechium edule (Jacq.) Swartz extracts. Food chemistry, 97(3): 452-458

Oyen, L.P.A., 2004. Beta vulgaris L. In G. B. H. Grubben and O. A. Denton (Eds.): Plant Resources of Tropical Africa 2. Vegetables (110-113). Wageningen: PROTA Foundations

Parra-Campos, A. and L.E. Ordóñez-Santos, 2019. Natural pigment extraction optimization from coffee exocarp and its use as a natural dye in French meringue. Food chemistry, 285: 59-66 
Ravichandran, K., N.M.M.T. Saw, A.A. Mohdaly, A.M. Gabr, A. Kastell, H. Riedel, and I. Smetanska, 2013. Impact of processing of red beet on betalain content and antioxidant activity. Food Research International, 50: 670-675.

Rekha, C.S., G. Poornima, M. Manasa, V. Abhipsa, J.P. Devi, H.T.V. Kumar, and T.R.P. Kekuda, 2012. Ascorbic acid, total phenol content and antioxidant activity of fresh juices of four ripe and unripe citrus fruits. Chemical Science Transactions, 1(2): 303-310.

Saani, M. and R. Lawrence, 2016. Evaluation of pigments as antioxidant and antibacterial agents from Beta vulgaris linn. International Journal of Current Pharmaceutical Research, 8(3): 37:41.

Sahar, S.A.S. and M.E.M.S. Manal, 2012. The effects of using color foods of children on immunity properties and liver, kidney on rats. Food and Nutrition Sciences, 3(7): 897-904

Singleton, V.L. and J.A.J. Rossi, 1965. Colorimetry of total phenolics with phosphomolybdicphosphotungstic acid reagents. Am. J. Enol. Vitic., 16:144-158.

Snedecor, G.W. and W.G. Cochran, 1980. Statistical methods. Oxford and J. B. H publishing Com. $7^{\text {th }}$ edition.

Stintzing, F.C., A. Schieber, and R. Carle, 2003. Evaluation of colour properties and chemical quality parameters of cactus juices. European Food Research and Technology, 216: 303-311.

Stintzing, F.C. and R. Carle, 2007. Betalains-emerging prospects for food scientists. Trends in Food Science and Technology 18(10): 514-525. 